\title{
4. EVALUATION OF PROGRAMMES IN PSYCHOMOTOR THERAPY
}

\author{
Zuzana Fábry Lucká 187
} Ivana Lištiaková ${ }^{188}$

\begin{abstract}
Psychomotoriktherapie orientiert sich an einem Pädagogischen-therapeutischen Konzept der Entwicklungsförderung. Sie Sich mit den befasst Wechselwirkungen Zwischen Wahrnehmen, Fühlen, Denken, Bewegen und verhalten, Eulen Deren körperlichem Ausdruck .Dieser Bericht bietet einen Überblick über die wissenschaftlichen Erkenntnisse Psychomotorische Therapie, welche ergänzende Komponenten dieser Programme können auf eine Verbesserung des emotionalen Wohlbefindens. Die Autorinnen realisiert die Bewertung der Psychomotorische Therapie-Programme im Hinblick auf die psychomotorische Komponenten (neuromotorik, senzomotorik, psychomotorik und sociomotorik). Die Ergebnisse zeigten, Unterschiede zwischen verschiedenen Programmen je nach $S$
\end{abstract}

Key words: Schlüsselbegriffe: Psychomotorische Therapie, Bewegung, Psychomotorik, Heilpädagogik

\section{Introduction ${ }^{189}$}

The goal of the paper is to analyze and evaluate programmes in psychomotor therapy, which were realized and published in master's theses of therapeutic educators. The goal of the evaluation was an effort to capture effective factors in psychomotor therapy in therapeutic education in its application in various client groups. The paper is constructed as a review study and a meta-analysis of conducted researches; however, it is based on the original research data, not on the analyses of findings. Researches published in the years 2000-2013 and realized as diploma researches of students of therapeutic education in the area of psychomotor therapy were included in the study. First, the authors of the paper define psychomotor therapy in therapeutic education and its place within the art therapies. They point out the components of psychomotor (neuromotor, sensory-motor, psychomotor and social-motor), which represent the establishing paradigms of setting goals in psychomotor therapy and the consecutive understanding of its effective factors. Expression of the clients in their own way becomes an artistic creative action in psychomotor therapy. People do not execute movements of the body automatically, but in a deeper connection with their mental activity and social interactions. The importance of body work in psychotherapy was, for example, proved by Davis $^{190}$. Art in movement is a means of self-expression also for people who do not have the possibility to express verbally and it has very strong positive therapeutic effects.

The first part of the study is oriented descriptively. It outlines the external factors of realized psychomotor programmes: target group from the perspective

\footnotetext{
${ }^{187}$ Mgr. PhD., Comenius University of Bratislava from Slovak Republic, lucka4@uniba.sk

${ }^{188}$ Mgr. PhD., Comenius University of Bratislava from Slovak Republic, listiakova@fedu.uniba.sk

${ }^{189}$ This research was supported by the KEGA project 067UK-4/2015 and KEGA project 069UK-4/2015

${ }^{190}$ Davis (2013)
} 
of the problem solved or the area of support and from the biodromal perspective (pre-natal age, early age, pre-school age, primary and secondary school age, adolescence, adulthood and senior age); frequency of sessions; length of programme and the number of recorded sessions.

The second part of the study is oriented analytically. The authors processed psychomotor programmes from the perspective of the components of psychomotor and evaluated them on a five-point scale according to the presence of these components as effective factors of psychomotor therapy. Based on this evaluation, the authors interpret the research results in the context of the theory of psychomotor therapy and its usage in various groups of clients.

\section{Theoretical background of psychomotor therapy}

Movement is a part of human being. It is present in heartbeat, breathing or blinking of the eye. Except the area of the human body, everything is surrounded by movement - in everyday life, in blowing of the wind, in rising of the sun during the day. Already in the past, movement was considered one of the ways in which the unconscious can gain a concrete form. ${ }^{191}$ According to Szabová ${ }^{192}$, movement is everywhere around us, it was connected with the development of our planet, the creation and development of life and humankind. Movement accompanies our life; it is in the air, water, fire, earth or in the nature. Movement is an expression of life, a means of communication and a source of self-awareness. It is a basic necessity of life. These all are definitions of movement as such. Psychomotor therapy is therapy through movement. It uses the characteristics of movement and its dynamics for expression of people. The main theoretical background of psychomotor therapy is psychomotor itself. This term first appeared before the end of the 19th century, then, however, describing an area of psychology dealing with the study of perception. ${ }^{193}$ Psychomotor in its most simple meaning indicates a close connection of motor functions (somatic activity) with psyche (mental activity). In this context, Kiphard ${ }^{194}$ wrote that the mental and physical area a human are in such close relationship that we have to look at them as at two sides of one happening. He also mentioned that psychomotor as such in its broader concept may be divided into certain components: neuromotor, sensory-motor, psychomotor and socialmotor. Neuromotor is the executive component of psychomotor, including fine and gross motor skills, movement coordination, body scheme, balance and orientation in space. ${ }^{195}$ Sensory-motor component concerns perception through sensory channels in the context of movement. Stimuli caught by sensory receptors are processed by the neuronal system and followed by a motor response. Psychomotor in the narrower sense indicated a direct connection of mental and movement functions of the organism. It includes motor activity caused by mental processes and states but also mental processes invoked by

\footnotetext{
${ }^{191}$ Jung, podl'a Szabová (1999)

192 Szabová (1998; 1999)

193 Zimmer (2006)

${ }^{194}$ Kiphard (1994)

195 Szabová (1999; 2003)
} 
movement. ${ }^{196}$ Social-motor is focused on group experiences and interactions of group members. It is a movement reaction to stimuli from the social environment. Moreover, through movement, people can express themselves towards the social environment, start interactions and relationships with close and more distant social surroundings.

Programmes in psychomotor therapy are based on theoretical knowledge base of therapeutic education, psychology, psychomotor therapy and also consultations with professionals necessary for solving clients' situations. A programme is a long-term goal-oriented intervention. It has a clear long-term goal and current short-term goals that stem from it and a clear structure dividing the programme into phases (according to the needs of clients and their difficulties). Creation of a programme in therapeutic education follows a biodromal perspective ${ }^{197}$ and is preceded by the process of assessment. In psychomotor therapy, similarly to other fields, various methods of data collection are used. According to Szabová ${ }^{198}$ the most common method is observation, which takes place in a spontaneous or specifically chosen situation. Lištiaková $^{199}$ wrote that depending on the focus of the programme, its specifications are selected: type (e.g.: stimulation, support, prevention or crisis intervention), length (e.g.: short-term, middle-length or long-term), target group (e.g.: child, adult, senior, parent or distant family member), frequency of sessions (e.g.: once a week, twice a week or every two weeks), length of a session, space and facilities necessary for conducting a specific type of programme. Examples of psychomotor programmes include: a programme for seniors (Carpe diem - Enjoy the day), a programme for mothers-to-be, a programme for mothers-to-be with children at risk, programmes for specific groups of clients (e.g.: women with muscular dystrophy, children with specific learning disorders, children with attention deficit disorder, adolescent women with eating disorders, or programmes of prevention for children from families at socio-economical risk). Setting the goals of the programmes is, according to Kováčová ${ }^{200}$ based on information gained from the assessment process - the goal can be, for example, supporting the physical "self" in persons with physical disabilities, anxiety disorder, or eating disorders; raising the concentration in children with specific learning disorder; or supporting social-motor functions at schools with integrated students with difficulties.

Based on the goals of the programme, particular phases of the programme are set. However, the beginning and ending phase are fixed in the structure. The first phase is introductory and the last phase is a closing, a relaxation phase, also called the phase of stabilization.

\footnotetext{
196 Szabová (1999; 2003)

${ }^{197}$ Kováčová (2014)

198 Ibidem

${ }^{199}$ Lištiaková (2015)

200 Kováčová (2015)
} 


\section{Research methodology}

For this research study, processes of quantitative and qualitative methodology were chosen. The source of the data were 12 researches conducted in the years 2000-2013 which were a part of masters' theses of students in the field of therapeutic education. Researches that were included in this study were selected based on these criteria: they were a part of a master's thesis; they were realized and defended in the field of therapeutic education; in the title and the content of the thesis, they stated psychomotor therapy and its techniques as the main methods of working with clients; they were conducted in the years 20002013; they included a transcript of observations of the sessions with clients including the description of the realized activities. The study focuses on the reanalysis of direct (raw) data from the original researches. The authors evaluated the processes and methods of psychomotor programmes based on their own key. The reason for the evaluation of the primary data instead of the evaluation of analysed data was the uneven level of data processing in the qualitative research of the masters' theses and the fact that it was not possible to compare the analysed phenomena. By analysing the original data, the quality of the analysis in the primary researches did not matter, because that did not concern the metaanalysis.

For the narrower quantitative analysis, only activities that constituted the core of the sessions were selected. Introductory and closing activities were omitted. Intrdouctory activities were mostly focused on a warm-up and preparation of the group for the main activity. On one hand, the warm-ups concerned physical work with the body, warming the muscles and motivating towards movement. On the other hand, warm-ups is also a psychological preparation for the topic of the session. Generally, the introductory activities were focused on all four components of psychomotor or they were in accordance with the goal area of the main technique of the session. The closing techniques were not included in the evaluation either. Those were mostly constituted by verbal or nonverbal reflection.

The goal of the evaluation was to provide an overview of the focus of psychomotor programmes from the perspective of goals of the programmes, therefore the partial goals of the introductions and closures would distort the results of the evaluation. Selected records of the main (core) activities of psychomotor programmes from the researches were analysed by the following methods of data processing and analysing:

a) qualitative methodology:

- qualitative content analysis of the transcript - records and descriptions of the programmes - by open coding;

- grouping content units (codes) into categories;

b) quantitative methodology:

- matching the categories to topics that are based on the theory of psychomotor therapy according to Szabová ${ }^{201}$. There were four topics named

${ }^{201}$ Szabová (1999) 
that respond to the four components of psychomotor: neuromotor (NE), sensorymotor (SE), psychomotor in the narrow sense (PS) an social-motor (SO);

- rating the items on a scale (1 to 5) according to the focus of the activity on a particular area of psychomotor $(1=$ no or very low focus, $2=$ low focus, $3=$ middle focus, $4=$ strong focus, $5=$ very high focus);

- quantitative evaluation of particular programmes (R1-R12) from the perspective of psychomotor components;

- comparison of findings in evaluated categories;

- comparison of findings of the ratio of psychomotor components regarding the characteristics of the programme from the perspective of the target group: a) according to the age of clients, b) according to the problem solved or a diagnostic category.

\section{Sample description}

The sample was constituted of data from 12 previously conducted researches. The total number of evaluated activities was 139. Table 1 presents the overview of the main areas of the psychomotor programmes. Based on these areas, therapeutic educators set the goals of the programmes. Table 2 is a description of the external factors that characterize the research sample of analyzed programmes.

Table 1 Orientation of psychomotor programme regarding the target group

\begin{tabular}{|l|l|}
\hline R1 & Support of relationships in an integrated kindergarten classroom \\
\hline R2 & $\begin{array}{l}\text { Supportive, supplementary therapy of adult women with depression during their hospitalization } \\
\text { at a psychiatry hospital }\end{array}$ \\
\hline R3 & Support of seniors with limited possibilities of movement, in an institution for elderly citizens \\
\hline R4 & $\begin{array}{l}\text { Support of adolescents with behavioural disorders hospitalized at a children psychiatry } \\
\text { department }\end{array}$ \\
\hline R5 & Stimulation programme for twins with cerebral palsy at primary-school age \\
\hline R6 & $\begin{array}{l}\text { Programme focused on support of emotional expression for children with speech disorders at a } \\
\text { primary boarding school }\end{array}$ \\
\hline R7 & $\begin{array}{l}\text { Programme focused on improving physical health conditions of adult women with cancer (35-55 } \\
\text { years old), long-term hospitalization }\end{array}$ \\
\hline R8 & Programme focused on school adaptation of children in the first year of primary school \\
\hline R9 & Programme for adolescents with low self-esteem \\
\hline R10 & Programme for adolescents with intellectual and combined disabilities \\
\hline R11 & Programme in a regular class at a primary school \\
\hline R12 & Programme for young women with muscular dystrophy \\
\hline
\end{tabular}

Table 2 Description of the external factors of the research sample

\begin{tabular}{|l|l|l|l|l|l|l|l|l|l|l|l|l|}
\hline & $\mathrm{R} 1$ & $\mathrm{R} 2$ & $\mathrm{R} 3$ & $\mathrm{R} 4$ & $\mathrm{R} 5$ & $\mathrm{R} 6$ & $\mathrm{R} 7$ & $\mathrm{R} 8$ & $\mathrm{R} 9$ & $\mathrm{R} 10$ & $\mathrm{R} 11$ & $\mathrm{R} 12$ \\
\hline Age group* & 1 & 4 & 5 & 3 & 2 & 2 & 4 & 2 & 3 & 3 & 2 & 4 \\
\hline $\begin{array}{l}\text { Number of clients in a } \\
\text { group }\end{array}$ & 13 & 6 & 5 & 6 & 2 & 6 & 9 & 23 & 8 & 10 & 23 & 4 \\
\hline $\begin{array}{l}\text { Frequency of sessios per } \\
\text { week }\end{array}$ & 1 & 3 & - & 3 & 2 & 2 & 3 & 3 & 2 & 1 & 1 & 2 \\
\hline $\begin{array}{l}\text { Length of programme in } \\
\text { months }\end{array}$ & 6 & 3 & 3 & 2 & 4 & 5 & - & - & 2 & 12 & 5 & 6 \\
\hline $\begin{array}{l}\text { Number of recorded } \\
\text { sessions }\end{array}$ & 8 & 15 & 14 & 10 & 8 & 15 & 9 & 12 & 11 & 10 & 10 & 12 \\
\hline $\begin{array}{l}\text { Number of analyzed } \\
\text { activities }\end{array}$ & 8 & 18 & 16 & 10 & 8 & 15 & 9 & 12 & 11 & 10 & 10 & 12 \\
\hline
\end{tabular}

*(1=pre-school age, $2=$ primary-school age, $3=$ adolescence, $4=$ adulthood, $5=$ senior age $)$ 


\section{Research results}

This paper focuses on the presentation of the results of the quantitative part of the research. The results of the first, qualitative, part created a starting point of the quantitative rating. Therefore, we consider their concretization as unnecessary for this research paper. The authors mention only illustrative vignettes from the qualitative part of the research, including a methodological example of coding.

\section{Illustrative vignettes from the qualitative part of the research}

Vignette 1 (R12): The therapist played a recording with oriental music rhythms and explained particular rhythms of the big and small Masmudi. The clients repeated them after the therapist. Their task was to perform the rhythm with the each part of the body. First with their head, then eyes, nose, mouth, shoulders, arms and hands, chest, belly and legs (code 1: rhythmic performance of the movement, code 2: manipulating the body parts, code 3: perceiving the group members). The whole session was accompanied by good mood in the group. A. repeated the rhythm with her eyes in a few different ways. K. joined the activity with laughter for the first time. She actively tried to think about a movement that nobody had used. After trying the rhythm on their own body, the clients were encouraged to "pass" the rhythm in the group by touching each other.

Vignette 2 (R12): In this session, rhythm was used. The therapist took a drum and gave verbal instruction: "As every dancer, also we need to learn to hear and feel a rhythm. We will pretend to be such dancers" (code: emotional experience through dramatization). The first body part was the chest - breathing with the lungs. The therapist gave a verbal instruction: "For every beat on the drum, we will breathe in as much as we can, so that the chest rises. Then we stop it and for the next beat of the drum, we will let the air go out of our lungs" (code: awareness of breathing).

Vignette 3 (R11): I moved to the right. We were making waves with the parachute and turning to the right. After that I suggested that we all squat and then stand up together (code: movement coordination in a group). The parachute got blown up. Children reacted with screaming. When we tried it for the second time, some children stood up too fast and some did not stand up at all. The parachute did not rise. B. suggested a play with simple rules. Everyone will blow up the parachute. One child will say a human characteristic (code: awareness of personality characteristics) and everyone who has it will change places (code 1: orientation in space, code 2: making contacts with other people in the group).

\section{Evaluation of the quantitative part of the research}

The quantitative analysis of activities realized in the programmes of psychomotor therapy contributed to the comparison of the ratio of the presence of particular psychomotor components in the therapy programmes. Table 3 provides an overview of the percentage of the four psychomotor components in the 12 analyzed programmes. In the area of neuromotor (NE) the highest rating was in program R7 (97.78\%). This was the highest evaluation rating of all the items. Generally, the lowest rating was in the area of psychomotor (PS) in two 
of the programmes ( $\mathrm{R} 1$ and $\mathrm{R} 8$ ). The average evaluation of the psychomotor components in all the programmes was rather balanced.

Table 3 Presence of psychomotor components in particular programmes

\begin{tabular}{|l|l|l|l|l|l|}
\hline Research & NE & SE & PS & SO & Average \\
\hline R1 & $62.50 \%$ & $70.00 \%$ & $35.00 \%$ & $50.00 \%$ & $54.38 \%$ \\
\hline R2 & $60.00 \%$ & $46.67 \%$ & $53.33 \%$ & $68.89 \%$ & $57.22 \%$ \\
\hline R3 & $57.50 \%$ & $56.25 \%$ & $61.25 \%$ & $61.25 \%$ & $59.06 \%$ \\
\hline R4 & $70.00 \%$ & $46.00 \%$ & $70.00 \%$ & $82.00 \%$ & $67.00 \%$ \\
\hline R5 & $75.00 \%$ & $65.00 \%$ & $50.00 \%$ & $57.50 \%$ & $61.88 \%$ \\
\hline R6 & $66.67 \%$ & $53.33 \%$ & $52.00 \%$ & $62.67 \%$ & $58.67 \%$ \\
\hline R7 & $97.78 \%$ & $53.33 \%$ & $48.89 \%$ & $35.56 \%$ & $58.89 \%$ \\
\hline R8 & $50.00 \%$ & $56.67 \%$ & $35.00 \%$ & $60.00 \%$ & $50.42 \%$ \\
\hline R9 & $60.00 \%$ & $43.64 \%$ & $67.27 \%$ & $76.36 \%$ & $61.82 \%$ \\
\hline R10 & $46.00 \%$ & $38.00 \%$ & $52.00 \%$ & $80.00 \%$ & $54.00 \%$ \\
\hline R11 & $80.00 \%$ & $86.00 \%$ & $48.00 \%$ & $84.00 \%$ & $74.50 \%$ \\
\hline R12 & $68.33 \%$ & $56.67 \%$ & $65.00 \%$ & $75.00 \%$ & $66.25 \%$ \\
\hline $\begin{array}{l}\text { Overall } \\
\text { evaluation }\end{array}$ & $66.15 \%$ & $55.96 \%$ & $53.15 \%$ & $66.10 \%$ & $60.34 \%$ \\
\hline
\end{tabular}

(NE=neuromotor, $\mathrm{SE}=$ sensory-motor, $\mathrm{PS}=$ psychomotor, $\mathrm{SO}=$ social-motor $)$

Figure 1 presents a comparison of the evaluation of the ratio of the presence of psychomotor components in the studied programmes according to the age of clients. The highest rating was present in the social-motor area in programmes for adolescents (79\%). That was followed by the neuromotor area in the programmes for adult clients $(75 \%)$ and by the sensory-motor area in programmes for children in pre-school age (70\%). The lowest rating was in the psychomotor area in the programmes for children in pre-school age (35\%) and primary-school age (46\%). Rather low rating was also in the sensory-motor area in the programmes for adolescents $(43 \%)$.

Figure 1 Comparison of the evaluation of the presence of psychomotor components according to the age category

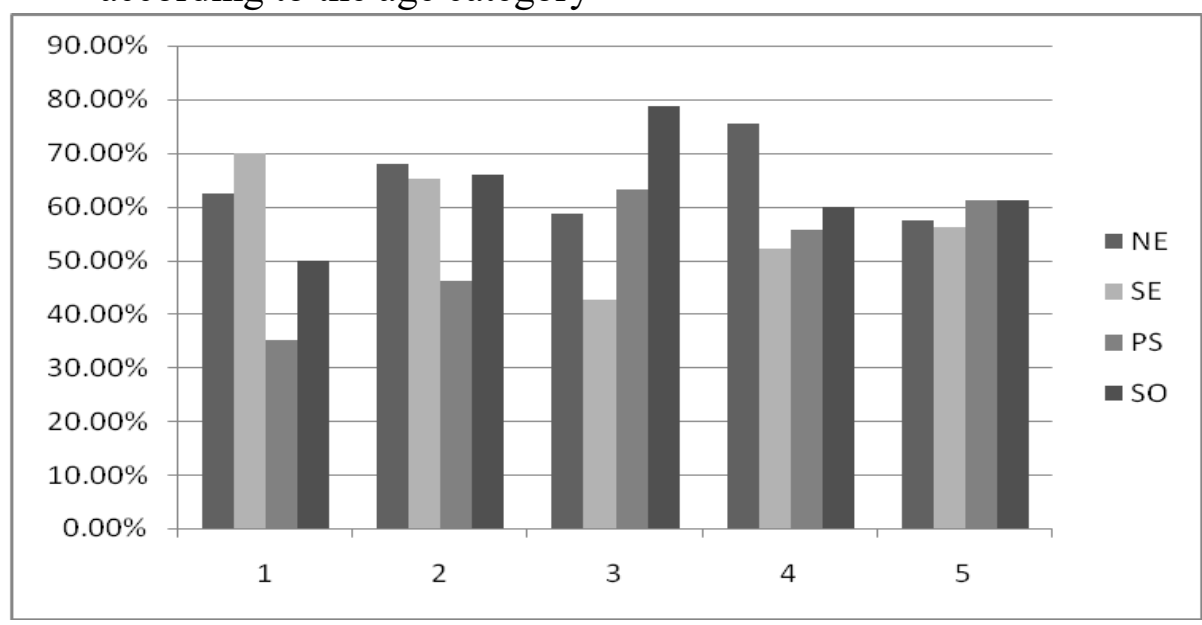

(NE NE=neuromotor, $\mathrm{SE}=$ sensory-motor, $\mathrm{PS}=$ psychomotor, $\mathrm{SO}=$ social-motor,

$1=$ pre-school age, $2=$ primary-school age, $3=$ adolescence, $4=$ adulthood, $5=$ senior age)

\section{Analysis and interpretation of the research results}

Psychomotor programmes which received a lower rating in all the psychomotor areas were orientated on the educational or compensation aspects. 
Programmes with a high rating, however, addressed therapeutic / psychotherapeutic goals. The highest rating $(97.78 \%)$ represented a programme strongly focused on the neuromotor area. It was orientated on supporting the physical health and well-being of the clients and it was realized in a close cooperation with a physiotherapist. The therapeutic effect lied in providing the opportunity to discuss the process of re-gaining physical strength after the cancer treatment. The lowest rating in the neuromotor area was noticed in the programme R10 (46\%). Despite being a psychomotor programme, it was focused more on emotions of clients and social interactions. It used techniques mixed with other art therapies. It followed the low motivation of clients to move. In the sensory-motor area, the highest rating was in the programme R11 $(86 \%)$. The programme used a parachute as one of the main materials. It is a highly sensory-material, therefore the activities scored high on the rating scale of sensory-motor area.

From the biodromal perspective, psychomotor programmes and their components reflect the developmental needs of clients, such as sensory play at pres-school age and its refusal in adolescence when the need of socialization is the most relevant. A high focus on the neuromotor part in programmes for adults was based on the needs of clients regarding rather their diagnosis than age. These were programmes for women with cancer, women with muscular dystrophy and women with depression.

\section{Conclusions}

The analysis and evaluation of psychomotor programmes brought a review of the focus and goals of psychomotor therapy in therapeutic education. The authors consider such analysis important, because it points out the typical characteristics and the essence of psychomotor therapy. In psychomotor therapy, movement is understood as uplifting and developing. Movement is understood as an artistic expression of a person in a form different from rational. Embodied work allows people to express themselves on a developmentally basal level. It contains cathartic and therapeutic effect. Through movement expression, people gain new insights and adopt new perspectives in their lives. The conducted analysis showed differences in particular programmes regarding the age of clients or the needs of the groups. However, it also recorded an overall balance in psychomotor programmes in therapeutic education regarding the presence of psychomotor components.

\section{References}

1. Bruncková, J. (2009). Psychomotorický program pre adolescentov so zníženým sebavedomím, [MA thesis], Univerzita Komenského, Bratislava

2. Davis, W., (2013). In support of body psychotherapy. International Body Psychotherapy Journal, 11(2), 59-73

3. Jokelová, D. (2003). Psychomotorická terapia u detí s poruchami správania, [MA thesis], Univerzita Komenského, Bratislava

4. Kiphard, E. (1994). Mototherapie Teil II. Dortmund: Modernes Lernen 
5. Kollárik, K. (2013). Psychomotorická terapia zameraná na sociálnu rehabilitáciu u mládeže s l'ahkým mentálnym postihnutím, [MA thesis], Univerzita Komenského, Bratislava

6. Kováčová, B. (2014). Liečebná pedagogika vo vývine človeka. In Kováčová, B. (Ed.), Liečebná pedagogika I. Vybrané kapitoly z liečebnej pedagogiky z biodromálneho hl'adiska, Univerzita Komenského, Bratislava

7. Kováčová, B. (Ed.) (2015). Liečebná pedagogika 2. Tvorba a evalvácia programu v liečebnej pedagogike. Univerzita Komenského, Bratislava

8. Krecháčová, M. (2001). Pohybový program pre Integrovanú materskú školu, [MA thesis], Univerzita Komenského, Bratislava

9. Lenhardová, L. (2003). Stimulačné psychomotorické cvičenia pre deti s detskou mozgovou obrnou v mladšom školskom veku, [MA thesis], Univerzita Komenského, Bratislava

10. Lištiaková, I. (2015). Programy v liečebnej pedagogike. In Kováčová, B. (Ed.), (2015). Liečebná pedagogika 2. Tvorba a evalvácia programu v liečebnej pedagogike. Univerzita Komenského, Bratislava

11. Lucká, Z. (2009). Psychomotorická terapia pre adolescentov a mladých dospelých s nervovo-svalovými ochoreniami, [MA thesis], Univerzita Komenského, Bratislava

12. Murínová, Z. (2009). Psychomotorické sprevádzanie $v$ triede $s$ integrovanými det'mi, [MA thesis], Univerzita Komenského, Bratislava

13. Müllerová, A. (2002). Využitie psychomotorickej terapie (pohybu) pri práci so seniormi, [MA thesis], Univerzita Komenského, Bratislava

14. Novotová, J. (2007). Využitie psychomotorickej terapie u dospelých pacientov, [MA thesis], Univerzita Komenského, Bratislava

15. Romančíková, N. (2006). Možnosti využitia psychomotorickej terapie u detí so zajakavost'ou, [MA thesis], Univerzita Komenského, Bratislava

16. Saso Bella, V. (2007). Využitie prvkov STOMP v psychomotorickej terapii a ich vplyv na celkovú adaptáciu diet’ata na školu, [MA thesis], Univerzita Komenského, Bratislava

17. Slabejová, A. (2001). Možnosti využitia psychomotorickej terapie u hospitalizovaných žien s depresiou, [MA thesis], Univerzita Komenského, Bratislava

18. Szabová, M. (1998). Náčrt psychomotorickej terapie. Pedagogická fakulta Univerzity Komenského, Bratislava

19. Szabová, M. (1999). Cvičení pro rozvoj psychomotoriky. $1^{\text {st }}$ ed., Portál, Praha

20. Szabová, M. (2003). Pohybom proti astme. LIEČREH GÚTH, Bratislava.

21. Zimmer, R. (2006). Handbuch der Psychomotorik. $8^{\text {th }}$ ed., Herder, Freiburg im Breisgau 